\title{
Effects of a ruminally protected B-vitamin supplement on milk yield and composition of lactating dairy cows
}

\author{
F.C. Sacadura ${ }^{a}$, P.H. Robinson ${ }^{\mathrm{a}, *}$, \\ E. Evans ${ }^{b}$, M. Lordelo ${ }^{c}$ \\ a Department of Animal Science, University of California, Davis, CA 95616, USA \\ ${ }^{\mathrm{b}}$ Essi Evans Technical Advisory Services, 64 Scugog St, Bowmanville, Ontario, Canada \\ ${ }^{c}$ Instituto Superior de Agronomia, Universidade Técnica de Lisboa, 1349 Lisbon, Portugal
}

Received 27 April 2007; received in revised form 26 September 2007; accepted 2 October 2007

\begin{abstract}
It is not clear if B vitamins supplied to the small intestine of dairy cows from dietary and rumen microbial sources are provided in sufficient quantity to maximize animal performance. Our objective was to determine effects of adding a ruminally protected B vitamin blend supplement, containing biotin, folic acid, pantothenic acid and pyridoxine, to the diet of high producing dairy cows on their productivity. Two dairy facilities located in California (USA) were used, one with mid lactation Holstein cows (Experiment 1) and the other with early lactation Holstein cows (Experiment 2). In each Experiment, cows were randomly assigned to treatment in a $2 \times 2$ crossover design with $28 \mathrm{~d}$ (Experiment 1) or $35 \mathrm{~d}$ (Experiment 2) experimental periods. In Experiment 1, milk and milk fat yield were unaffected by treatment, although milk fat proportion was lower $(37.1$ versus $36.3 \mathrm{~g} / \mathrm{kg}$; $\mathrm{P}<0.01)$, but milk protein yield was higher $(1.21$ versus $1.24 \mathrm{~kg} / \mathrm{d} ; \mathrm{P}=0.02)$ in cows fed $\mathrm{B}$ vitamins. In Experiment 2, milk (39.60 versus $40.46 \mathrm{~kg} / \mathrm{d} ; \mathrm{P}=0.02)$, milk fat $(1.40$ versus $1.47 \mathrm{~kg} / \mathrm{d} ; \mathrm{P}<0.01$ ) and milk protein yield (1.10 versus $1.16 \mathrm{~kg} / \mathrm{d} ; \mathrm{P}<0.01)$, as well as milk energy output (113.2 versus $117.8 \mathrm{MJ} / \mathrm{d} ; \mathrm{P}<0.01)$ were all higher with $\mathrm{B}$ vitamin feeding. Body condition score (BCS) increased
\end{abstract}

Abbreviations: ADICP, acid detergent insoluble CP; ADF, acid detergent fiber; BCS, body condition score; BLS, body locomotion score; BW, body weight; CP, crude protein; DM, dry matter; Andf, neutral detergent fiber; NE, net energy; NRC, national research council; OM, organic matter; SCC, somatic cell count; TMR, total mixed ration.

* Corresponding author. Tel.: +1 5307547565.

E-mail address: phrobinson@ucdavis.edu (P.H. Robinson). 
more with B vitamin feeding in Experiment 2, but was unaffected in Experiment 1. Body locomotion score (BLS) increased with B vitamin feeding in both experiments ( $\mathrm{P}=0.01$ and $<0.01$, respectively), possibly an indication of reduced locomotory ability. Overall, productivity of high producing lactating dairy cows responded positively to feeding a mixture of ruminally protected B vitamins, although differences in the extent of the positive responses between experiments perhaps suggests that early lactation cows, with lower DM intake to milk yield ratios, may be more responsive to ruminally protected B vitamins than mid lactation cows, with higher DM intake to milk yield ratios.

(C) 2007 Published by Elsevier B.V.

Keywords: Biotin; Folic acid; Pantothenic acid; Pyridoxine; Dairy cattle; Milk protein

\section{Introduction}

Water-soluble B vitamins are indispensable nutrients for all mammalian species and are obligatory for regulation of metabolic processes. The functions of these compounds are wide ranging and impact health and productivity. Early research into dietary needs of ruminants for B vitamins (McElroy and Goss, 1940a, 1940b; Lardinois et al., 1944; Agrawala et al., 1953) showed that even when relatively B vitamin-free diets were fed, ruminants were able to meet their B vitamins need from those that were synthesized in the rumen and, as a result, this research topic was largely ignored. Later research with steers (Zinn et al., 1987) showed that ruminal destruction and microbial synthesis differed among B vitamins, but that B vitamin appearance in the small intestine generally exceeded that provided by feed. Due to these studies, it was often assumed that the ruminal microbial population synthesizes B vitamins, making additional supplementation to dairy cows unnecessary.

Milk production in dairy cows continues to increase and, increasing with it, are animal nutrient requirements. That high yielding dairy cows could be susceptible to marginal $\mathrm{B}$ vitamin status due to high metabolic rates during lactation (Seymour, 2000) generated renewed interest in possible roles of B vitamins in nutrition of dairy cows. Some recent studies have reported that an increased supply of one or more B vitamins had a beneficial effect in lactation performance. For example, multiparous cows fed $4 \mathrm{mg}$ of folic acid/ $\mathrm{kg}$ of body weight $(\mathrm{BW}) /$ day produced $6 \%$ (i.e., $2.2 \mathrm{~kg} / \mathrm{d}$ ) more milk than unsupplemented cows during the first 100 days of lactation and produced $10 \%$ more (i.e., $3 \mathrm{~kg} / \mathrm{d}$ ) milk from 100 to 200 days of lactation (Girard and Matte, 1998). A similar increase in milk production occurred in multiparous cows that received a parenteral supplement of folic acid during the last half of lactation (Girard et al., 1995). Zimmerly and Weiss (2001) fed dairy cows 0,10 or $20 \mathrm{mg} / \mathrm{d}$ of supplemental biotin, starting 14 days pre-calving through 100 days of lactation, and reported a positive linear effect on milk production. Majee et al. (2003) observed an increase in milk and milk protein production with $20 \mathrm{mg} / \mathrm{d}$ of supplemental biotin, and Girard and Matte (2005) demonstrated that weekly injections of $10 \mathrm{mg}$ of vitamin $\mathrm{B}_{12}$ increased milk production in heifers receiving high levels of folic acid ( $4 \mathrm{mg} / \mathrm{kg}$ of body weight/day) from day 25 to 125 of lactation. Other research has shown that thiamin added to the diet (150-300 mg/d) increased milk and milk component yields in dairy cows (Shaver and Bal, 2000). 
The only study that examined supplementation of dairy cows with a B vitamin blend was that of Majee et al. (2003), who compared a B vitamin blend to biotin and determined that there was no additional response to the blend, which suggested that ruminal protection would be required. This experiment demonstrated that simply altering the dietary supply of a B vitamin might not impact the amount of it that is absorbed, probably because rumen microbes extensively destroy some B vitamins (Santschi et al., 2005). To deliver an accurate $\mathrm{B}$ vitamin dose to the intestinal absorptive site, $\mathrm{B}$ vitamins need to be injected, duodenally infused or ruminally protected.

NRC (2001) estimated B vitamin requirements of lactating dairy cows by summing requirements for maintenance, extrapolated from $173 \mathrm{~kg}$ lactating sows to $630 \mathrm{~kg}$ lactating cows with net output in milk at $35 \mathrm{~kg}$ /day. Based upon the best information available at the time of publication, NRC (2001) projections showed that folic acid and pantothenic acid would likely be nutritionally limiting. Furthermore, assuming that B vitamins are typically in the range of the control diets described by Santschi et al. (2005) and Schwab et al. (2006), the estimated deficit for folic acid would be in the range of 7-12 mg/day, while the deficit for pantothenic acid most likely be in the range of 80-120 mg. Research conducted since NRC (2001) has been published (Santschi et al., 2004; Schwab et al., 2006) and shows that pyridoxine flow to the intestine would be 50-70 mg less than NRC (2001) computed requirements. Other vitamins, including biotin, did not appear to be in short supply.

In North America, usual supplementation rates for biotin are $20 \mathrm{mg} / \mathrm{day}$, regardless of level of production (Majee et al., 2003). Approximately half of the added biotin is destroyed in the rumen (Santschi et al., 2005; Frigg et al., 1993), resulting in about $10 \mathrm{mg} /$ day delivered.

Thus the question remains as to whether B-vitamins are available in sufficient amounts to support milk production and milk protein synthesis during lactation. The objective of this study was to determine effects of adding a ruminally protected B vitamin complex of biotin $(10 \mathrm{mg})$, folic acid $(12 \mathrm{mg})$, pantothenic acid $(120 \mathrm{mg})$ and pyridoxine $(75 \mathrm{mg})$ to the total mixed ration of early, and mid, lactation Holstein cows on feed intake, milk production and milk composition.

\section{Materials and methods}

\subsection{B vitamin blend}

A ruminally protected B vitamin blend (VicombP+, Jefo Nutrition Inc., St. Hyacinthe, QC, Canada) was formulated to contain B vitamins (i.e., biotin, folic acid, pantothenic acid, pyridoxine; Table 1) considered to be supplied at sub-optimal levels, at levels discussed in Section 1. Based upon the rumen inert nature of two saturated fatty acids that are digestible in the small intestine (Table 1), the high ruminal in situ recovery of $\mathrm{N}$ from the matrix at $24 \mathrm{~h}$ of incubation (i.e., $930 \mathrm{~g} / \mathrm{kg} \mathrm{N}$; results in Table 1 and method used in Section 2.4), as well as the specific gravity of the matrix (i.e., 1.19, Table 1) which is within the range shown by Welch (1990) to maximize rumen particle escape, it was concluded that the technology to encapsulate the B vitamins in a saturated fatty acid matrix minimized rumen release of the $\mathrm{B}$ vitamins. 
Table 1

Analyzed $^{\mathrm{a}}$ and guaranteed B vitamin composition $(\mathrm{mg} / \mathrm{g})$ of the B vitamin blend (i.e., Vicomb $\left.\mathrm{P}+\right)^{\mathrm{b}, \mathrm{c}}$

\begin{tabular}{lllll}
\hline & Biotin & Folate & Pantothenic acid & Pyridoxine \\
\hline Analyzed & $3.22 \pm 0.075$ & $4.23 \pm 0.157$ & $64.31 \pm 0.677$ & $26.49 \pm 1.194$ \\
Guaranteed & 3.20 & 4.00 & 40.00 & 25.00 \\
\hline
\end{tabular}

Vicomb $\mathrm{P}+$ had a measured ruminal in situ recovery of $930 \pm 3.30 \mathrm{~g} / \mathrm{kg} \mathrm{N}$ at $24 \mathrm{~h}$ of incubation.

a $n=10$.

b Vicomb P+ also contained 396 g/kg DM of total fatty acids with C16:0 (615 g/kg total fatty acids) and C18:0 ( $356 \mathrm{~g} / \mathrm{kg}$ total fatty acids) comprising the bulk of the fatty acids.

c Vicomb P+ had a measured specific gravity of $1.19 \pm 0.016$ and a measured in situ recovery of $930 \pm 3.30 \mathrm{~g} / \mathrm{kg}$ $\mathrm{N}$ at $24 \mathrm{~h}$ of incubation.

The B vitamin blend was blended with $18.2 \mathrm{~kg}$ of wheat millrun, at a level based on the number of cows to which it would be fed, to achieve feeding levels of $3 \mathrm{~g} / \mathrm{cow} / \mathrm{d}$ of $\mathrm{B}$ vitamin blend. The control bags only contained wheat millrun. Bags were supplied colour coded by treatment and feeding and management personal were not informed of the treatments.

The B vitamin blend was sampled from two randomly selected bags on three occasions (i.e., at receipt prior to the study, near the end of the study and about 2 months after the study) for subsequent B-vitamin assay. The samples, except those collected 2 months after the study, were analyzed in two different assay runs.

\subsection{Experiment 1}

Mid-lactation Holstein cows on a commercial dairy near Lodi (CA, USA) were used. The pens of cows were two mid lactation groups, to which mid lactation primiparous or multiparous cows, in a ratio of 0.31:0.69, were randomly allocated from the early lactation pens by the herd manager. After cows were assigned to a pen, cow movement was allowed out of that pen to a common alternate pen that was not utilized in the study. A total of 247 cows $(218.8 \pm 3.90$ days in milk at the start) in two very similar pens were used in a $2 \times 2$ cross over design with 28 day experimental periods. Cow groups (i.e., pens of cows) were selected from several potential commercial dairy herds based on the similarity of their milk production and milk composition prior to initiating the study. Cows were housed in a free stall barn with sand bedded stalls, and had access to dry lots and water ad libitum. Pens were randomly assigned to control or B vitamin blend treatments. The study occurred from May to July 2006, when high and low environmental temperatures averaged 32 and $13{ }^{\circ} \mathrm{C}$, relative humidity averaged $51 \%$, and there were few rain events.

Cows were fed a totally mixed ration (TMR) twice daily, between 05:00 and 06:00 $\mathrm{h}$ and 13:00 and 14:00 h ad libitum. Intake was measured using the Feed Watch system (Valley Agriculture Software, Tulare, CA, USA) to record the total amount of DM offered. Orts were removed and measured daily. The basal TMR was the same for both treatment groups (Table 2), and it differed only in that the B vitamin blend was added to the morning feeding at a level designed to deliver $3 \mathrm{~g} / \mathrm{cow} / \mathrm{d}$ of $\mathrm{B}$ vitamin blend. The chemical composition of the TMR is in Table 3.

Cows were milked twice daily between 11:30 and 13:30 $\mathrm{h}$ and between 23:30 and 01:30 h (pen 1) and between 13:30 and 15:30 h and between 01:30 and 03:30 (pen 2), in both experimental periods, in a herringbone style milking parlor. 
Table 2

Ingredient composition of the TMR ${ }^{\mathrm{a}}(\mathrm{g} / \mathrm{kg} \mathrm{DM})$ fed in Experiments 1 and 2

\begin{tabular}{|c|c|c|}
\hline & Control & $B$ vitamin blend \\
\hline \multicolumn{3}{|l|}{ Experiment 1} \\
\hline Corn silage & 152.2 & 152.3 \\
\hline Alfalfa silage & 113.0 & 110.3 \\
\hline Alfalfa hay & 100.5 & 98.6 \\
\hline Wet brewers grains & 39.2 & 39.6 \\
\hline Corn grain, flaked & 252.3 & 254.4 \\
\hline Cottonseed, whole linted & 128.8 & 129.6 \\
\hline Canola, pellets & 159.5 & 160.5 \\
\hline Beet pulp, dehy shreds & 34.5 & 34.6 \\
\hline Mineral premix & 17.1 & 17.2 \\
\hline B-vitamin blend ${ }^{b}$ & 2.8 & - \\
\hline Control (wheat, millrun) & - & 2.8 \\
\hline \multicolumn{3}{|l|}{ Experiment 2} \\
\hline Corn silage & 108.5 & 108.6 \\
\hline Alfalfa haylage & 102.0 & 101.9 \\
\hline Wheat Silage & 29.9 & 30.2 \\
\hline Alfalfa hay & 115.4 & 116.0 \\
\hline Corn grain, flaked & 228.9 & 228.0 \\
\hline Cottonseed, whole linted & 100.3 & 100.9 \\
\hline Corn distillers grains, dehy with solubles & 59.4 & 59.4 \\
\hline Soybean, hulls & 67.0 & 67.0 \\
\hline Soybean, meal $48 \% \mathrm{CP}$ solvent & 50.8 & 50.8 \\
\hline Oat Hay & 14.7 & 14.7 \\
\hline Wheat, millrun & 47.0 & 43.9 \\
\hline Liquid whey & 42.7 & 42.3 \\
\hline Mineral premix & 26.3 & 26.3 \\
\hline EnerG II rumen inert fat & 7.2 & 6.8 \\
\hline $\mathrm{B}$ vitamin blend ${ }^{\mathrm{b}}$ & - & 3.1 \\
\hline Control (wheat, millrun) & 3.1 & - \\
\hline
\end{tabular}

${ }^{\text {a }}$ Replicate samples pooled by period ( $n=2$ per column).

b $\mathrm{B}$ vitamin blend-960 g/kg Wheat mill run, $40 \mathrm{~g} / \mathrm{kg}$ Vicomb P+.

Body condition score (BCS; Edmonson et al., 1989) and body locomotion score (BLS; Sprecher et al., 1997) were scored by three experienced persons at the beginning and end of each experimental period by observing cows coming from the milk parlor to the freestall barn after being milked.

The TMR, and individual dietary ingredients and premixes, were sampled on days 20 and 26 of each experimental period. The TMR was sampled by taking about 10 samples of approximately $2000 \mathrm{~cm}^{3}$, at evenly spaced increments along the $125 \mathrm{~m}$ feed bunk. Silages were collected by sampling approximately five locations from the silage face. Alfalfa hay was sampled using a 'golf club' style hay probe that measured $30 \mathrm{~cm}$ in length and was $1 \mathrm{~cm}$ in diameter (Sierra Testing Services, Acampo, CA, USA). Approximately 12 core samples were pooled to make up each sample. All other ingredients were sampled by hand and bagged in plastic for transport to University of California at Davis for later chemical analyses. 
Table 3

Chemical composition of $\mathrm{TMR}^{\mathrm{a}}$ fed in Experiment 1

\begin{tabular}{|c|c|c|c|c|}
\hline & Control & $\mathrm{B}$ vitamin blend & S.E.M. & $\mathrm{P}$ \\
\hline $\mathrm{DM}(\mathrm{g} / \mathrm{kg})$ & 594.1 & 570.8 & 5.22 & 0.45 \\
\hline \multicolumn{5}{|l|}{$\mathrm{g} / \mathrm{kg}$ of $\mathrm{DM}$} \\
\hline $\mathrm{OM}$ & 926.6 & 927.3 & 2.47 & 0.85 \\
\hline aNDf & 320.5 & 319.3 & 3.32 & 0.81 \\
\hline aNDFom & 307.5 & 307.8 & 3.31 & 0.96 \\
\hline $\mathrm{ADF}$ & 226.0 & 225.8 & 2.95 & 0.95 \\
\hline ADFom & 214.0 & 215.5 & 2.74 & 0.72 \\
\hline Lignin(sa) & 62.3 & 59.5 & 1.26 & 0.18 \\
\hline $\mathrm{CP}$ & 186.3 & 185.0 & 3.06 & 0.79 \\
\hline $\mathrm{ADICP}^{\mathrm{b}}$ & 15.0 & 15.6 & 0.88 & 0.57 \\
\hline Freeglucose & 6.8 & 7.0 & 0.53 & 0.75 \\
\hline Starch & 189 & 185 & 9.79 & 0.77 \\
\hline $\mathrm{Ca}$ & 8.3 & 8.3 & 0.34 & 0.96 \\
\hline $\mathrm{P}$ & 5.8 & 5.7 & 0.07 & 0.65 \\
\hline $\mathrm{K}$ & 12.9 & 13.2 & 0.71 & 0.76 \\
\hline $\mathrm{Mg}$ & 3.9 & 3.9 & 0.01 & 0.65 \\
\hline S & 3.0 & 3.0 & 0.30 & 0.98 \\
\hline $\mathrm{Na}$ & 2.6 & 2.6 & 0.25 & 0.82 \\
\hline $\mathrm{Cl}$ & 2.6 & 2.5 & 0.13 & 0.90 \\
\hline \multicolumn{5}{|l|}{$\mathrm{mg} / \mathrm{kg}$ of $\mathrm{DM}$} \\
\hline $\mathrm{Zn}$ & 93.0 & 98.0 & 5.81 & 0.57 \\
\hline $\mathrm{Mn}$ & 78.5 & 79.8 & 2.89 & 0.77 \\
\hline $\mathrm{Fe}$ & 302.3 & 279.0 & 17.68 & 0.40 \\
\hline $\mathrm{Cu}$ & 9.1 & 9.5 & 0.31 & 0.33 \\
\hline $\mathrm{Co}$ & 0.48 & 0.43 & 0.052 & 0.53 \\
\hline Mo & 1.03 & 1.05 & 0.133 & 0.90 \\
\hline $\mathrm{Se}$ & 0.65 & 0.57 & 0.032 & 0.12 \\
\hline
\end{tabular}

${ }^{\text {a }}$ Replicate samples pooled by period ( $n=2$ per column).

b Acid detergent insoluble CP.

Milk samples were collected over the last two days of each experimental period during the regularly scheduled monthly Dairy Herd Improvement Association (San Joaquin DHIA, Manteca, CA, USA) milk test, from both the morning and evening milking. The DHIA personnel obtained about $50 \mathrm{ml}$ of milk from each cow using Tru-Test WB110 sampling meters (Tru-Test Ltd., Auckland, New Zealand). Fresh milk samples obtained by DHIA personnel were treated with a preservative containing bronopol and natamycin and transported to the San Joaquin DHIA Laboratory for analysis of fat, true protein and somatic cells.

\subsection{Experiment 2}

Experiment 2 followed a very similar protocol to Experiment 1, with the major difference being that 247 early lactation multiparous Holstein cows $(92.8 \pm 1.96$ days in milk at the start) on a commercial dairy near Madera (CA, USA) were used in a $2 \times 2$ cross over design with 35 day experimental periods. Cow groups (i.e., pens of cows), selected from several potential commercial dairy herds based on the similarity of their milk production and milk 
Table 4

Chemical composition of total mixed rations ${ }^{\mathrm{a}}$ fed in Experiment 2

\begin{tabular}{lllll}
\hline & Control & B vitamin blend & S.E.M. & P \\
\hline DM g/kg, as fed & 568.1 & 600.7 & 2.33 & 0.03 \\
g/kg of DM & & & & \\
OM & 914.8 & 910.8 & 1.32 & 0.08 \\
aNDF & 311.2 & 318.5 & 6.26 & 0.45 \\
aNDFom & 301.5 & 308.8 & 5.70 & 0.41 \\
ADF & 217.0 & 220.8 & 5.99 & 0.68 \\
ADFom & 208.3 & 212.0 & 5.64 & 0.66 \\
Lignin(sa) & 46.8 & 45.8 & 1.57 & 0.67 \\
CP & 178.1 & 177.5 & 2.50 & 0.90 \\
ADICP & 15.0 & 15.0 & 1.00 & 1.00 \\
Freeglucose & 6.0 & 6.5 & 0.67 & 0.62 \\
Starch & 172 & 165 & 10.3 & 0.37 \\
Ca & 11.3 & 11.4 & 0.53 & 0.87 \\
P & 4.9 & 5.1 & 0.09 & 0.28 \\
K & 18.6 & 19.7 & 0.62 & 0.24 \\
Mg & 3.5 & 3.4 & 0.07 & 0.82 \\
S & 2.7 & 2.8 & 0.06 & 0.44 \\
Na & 3.4 & 3.4 & 0.13 & 0.93 \\
Cl & 5.6 & & 0.23 & 0.43 \\
mg/kg of DM & & & & \\
Zn & 104.8 & 107.3 & 5.12 & 0.74 \\
Mn & 69.8 & 70.8 & 2.51 & 0.79 \\
Fe & 306.5 & 16.3 & 6.77 & 0.48 \\
Cu & 16.5 & 16.3 & 0.45 & 0.82 \\
Co & 0.58 & 0.55 & 0.043 & 0.70 \\
Mo & 1.00 & 0.53 & 0.115 & 0.77 \\
Se & 0.57 & & & 0.045 \\
\hline & & & &
\end{tabular}

${ }^{\text {a }}$ Replicate samples pooled by period ( $n=2$ per column).

b Acid detergent insoluble CP.

composition, were the two high producing groups on the dairy, to which fresh (i.e., newly calved) multiparous cows were randomly allocated from the fresh pen by the herd manager. After cows were assigned to a pen, movement was allowed out of that pen to a common alternate pen that was not utilized in the study.

Cows were fed a TMR twice daily, between 05:00 and 06:00 and 13:30 and 14:30 h to appetite. Intake was measured using the Feed Watch System to record the total amount of DM offered. Orts were removed and measured every other day. The basal TMR was the same for both treatment groups (Table 2), and differed only in that the B vitamin blend was added to the afternoon feeding of treated cows at a level designed to deliver $3 \mathrm{~g} / \mathrm{cow} / \mathrm{d}$ of $\mathrm{B}$ vitamin blend. The chemical composition of the TMR is in Table 4.

Cows were milked three times daily between 06:00 and 07:30, 13:30 and 15:00, and 21:00 and 22:30 h (pen 1) and between 07:30 and 09:00, 17:00 and 18:30, and 00:30 and 02:00 (pen 2), in both experimental periods, in a herringbone style milking parlor.

Body condition and body locomotion were scored by three experienced persons at the beginning and end of each experimental period as in Experiment 1. The TMR, individual 
dietary ingredients and premixes were sampled weekly, following the same protocol as described in Experiment 1.

Milk samples were collected on the last two days of each experimental period during the regularly scheduled monthly DHIA (Fresno, CA, USA) milk test, at all three milkings. The same procedure to collect the milk samples was used as in Experiment 1.

\subsection{Analytical methods}

Feed samples were ground to pass a 40 mesh screen on an Intermediate Wiley Mill or a $1 \mathrm{~mm}$ screen on a model 4 Wiley Mill. Determination of moisture was by gravimetric loss of free water by heating to $105^{\circ} \mathrm{C}$ in a forced air oven for $2 \mathrm{~h}$ (Reuter et al., 1986). Neutral detergent fiber analysis included sodium sulphite and used a heat stable amylase (Van Soest et al., 1991) and is expressed both inclusive (aNDF) and exclusive (aNDFom) of residual ash. Acid detergent fiber was determined according to methods of the Association of Official Analytical Chemists (AOAC, 1997a) and is expressed both inclusive (ADF) and exclusive (ADFom) of residual ash. Lignin(sa) was determined by the sulfuric acid procedure (AOAC, 1997a). Ash was determined as gravimetric residue after heating to $550^{\circ} \mathrm{C}$ for $8 \mathrm{~h}$. Starch was determined by enzymatic hydrolysis (Smith, 1969) and free glucose was determined by a high performance liquid chromatography (HPLC) method (Johansen et al., 1996). Total fat in feeds was determined as that material extracted in ether (AOAC, 2000, ID 930.39).

The P, S, Ca, Mg, Na, B, Zn, Mn, Fe, Cu, Co and Mo levels were determined utilizing a nitric acid/hydrogen peroxide microwave digestion and atomic absorption spectrometry (AAS) or inductively coupled plasma atomic emission spectrometry (ICP-AES; Sah and Miller, 1992; Meyer and Keliher, 1992). Total K was extracted by $20 \mathrm{~g} / \mathrm{L}$ acetic acid and determined by atomic emission spectrometry (AES; Johnson and Ulrich, 1959). Total Cl was extracted by $20 \mathrm{~g} / \mathrm{L}$ acetic acid extraction and determined by chloridometer (Johnson and Ulrich, 1959). Total Se was extracted by nitric/perchloric acid digestion/dissolution and determined by vapor generation using inductively coupled plasma atomic emission spectroscopy (ICP-AES; Tracy and Moeller, 1990). The CP and ADICP levels were determined with an $\mathrm{N}$ Gas Analyzer utilizing induction furnace and thermal conductivity (LECO FP-528; AOAC, 1997b).

All four B vitamins were assayed using AOAC (2000) microbiological procedures by Silliker Laboratories (Markham, ON, Canada) by method 960.46 for biotin, method 945.74 for pantothenic acid, method 961.15 for pyridoxine and method 944.12 for folates.

In situ ruminal stability of the B vitamins in the B vitamin blend was estimated using a standard ruminal in sacco procedure that utilized two ruminally cannulated lactating cows with six replicate in sacco bags incubated in each cow from each of two batches of the B vitamin blend (i.e., Vicomb $\mathrm{P}+$ ). As the only source of $\mathrm{N}$ in the $\mathrm{B}$ vitamin blend was in the $\mathrm{B}$ vitamins, $\mathrm{B}$ vitamin stability was estimated the recovery of $\mathrm{N}$ at $24 \mathrm{~h}$ of ruminal incubation.

\subsection{Calculations}

The DM intake was determined in the final week (i.e., days 22-28 (Experiment 1) or 29-35 (Experiment 2)) by dividing total pen DM intake by the average number of cows in 
the pen in that week. Changes in BCS and BLS were calculated within cow by difference (i.e., BCS/BLS at end of period minus BCS/BLS at beginning of period). Changes in BCS and BLS in tables are reported as change/30 d.

Milk energy was calculated according to Tyrrell and Reid (1965) using the formula for milk fat and protein.

\subsection{Statistical analysis}

Results were statistically analyzed by experiment as $2 \times 2$ factorial designs with pen and treatment as model classes using 'pen' as the experimental unit for DM intake and TMR components (GLM option of SAS, 1998), and with 'period', 'pen' and 'treatment' as model classes, with nesting of 'cow' within 'pen' in the 'random' statement of the model for other parameters (MIXED option of SAS, 1998). Milk production parameters were analyzed for those cows that were in their initially assigned pen for the entire experiment (coincidentally, $n=247$ for each experiment). Significant differences were accepted if $\mathrm{P} \leq 0.05$ and tendencies to significance were accepted if $0.05<\mathrm{P} \leq 0.10$.

\section{Results}

\subsection{Experiment 1 (mid lactation cows)}

The chemical composition of the TMR (Table 3) was similar to that expected, based on the formulation of the rations and the composition of the ingredients (Table 2). All TMR mineral levels met or exceeded NRC (2001) recommendations with, for example, Ca $(8.3 \mathrm{~g} / \mathrm{kg}$ versus $6.3 \mathrm{~g} / \mathrm{kg}), \mathrm{P}(5.8 \mathrm{~g} / \mathrm{kg}$ versus $3.6 \mathrm{~g} / \mathrm{kg})$ and $\mathrm{Se}(0.61 \mathrm{ppm}$ versus $0.30 \mathrm{ppm})$ being noticeably higher. The only mineral with a lower level than that recommended by NRC (2001) was $\mathrm{Cu}$, at $9.3 \mathrm{ppm}$ versus the $11.0 \mathrm{ppm}$ level recommended by NRC (2001). However there was no difference in the chemical composition of the TMR fed to the Control versus $\mathrm{B}$ vitamin blend cows.

The milk yield, milk energy output and milk protein yield were unaffected by B vitamin feeding (Table 5). However milk protein yield was higher $(\mathrm{P}<0.05)$ in cows fed $\mathrm{B}$ vitamins, and milk fat proportion was lower $(\mathrm{P}<0.01)$ with $\mathrm{B}$ vitamin feeding.

The BCS was unaffected by treatment, as were changes in BCS. While BLS was also unaffected, changes in BLS were higher $(-0.02$ versus 0.13 units $/ 30 \mathrm{~d} ; \mathrm{P}=0.01)$ for cows fed B vitamins (Table 5).

\subsection{Experiment 2 (early lactation cows)}

As in Experiment 1, the chemical composition of the TMR (Table 4) was similar to that expected based on the formulation of the rations and the chemical composition of the ingredients (Table 2). All TMR mineral levels exceeded NRC (2001) recommendations, but there was no difference between the chemical composition of the TMR fed to the Control versus $\mathrm{B}$ vitamin blend cows, except for $\mathrm{DM}$, which was slightly higher $(\mathrm{P}<0.05)$ in the $\mathrm{B}$ vitamin blend TMR. 
Table 5

Impact of feeding B vitamins on DM intake and production of cows ${ }^{\mathrm{a}}$ in Experiment 1

\begin{tabular}{|c|c|c|c|c|}
\hline & Control & $\mathrm{B}$ vitamin blend & S.E.M. & $\mathrm{P}$ \\
\hline DM intake $(\mathrm{kg} / \mathrm{d})$ & 24.3 & 24.1 & 0.86 & 0.91 \\
\hline \multicolumn{5}{|l|}{ Yield } \\
\hline Milk (kg/d) & 39.77 & 40.30 & 0.501 & 0.12 \\
\hline Fat $(\mathrm{kg} / \mathrm{d})$ & 1.47 & 1.45 & 0.020 & 0.29 \\
\hline True protein $(\mathrm{kg} / \mathrm{d})$ & 1.21 & 1.24 & 0.015 & 0.02 \\
\hline Energy $(\mathrm{MJ} / \mathrm{d})$ & 118.2 & 118.5 & 1.45 & 0.78 \\
\hline \multicolumn{5}{|l|}{ Milk components } \\
\hline Fat $(\mathrm{g} / \mathrm{kg})$ & 37.1 & 36.3 & 0.34 & $<0.01$ \\
\hline True protein $(\mathrm{g} / \mathrm{kg})$ & 30.6 & 30.8 & 0.13 & 0.06 \\
\hline Energy $(\mathrm{MJ} / \mathrm{kg})$ & 2.98 & 2.95 & 0.014 & 0.02 \\
\hline SCC ('000) & 281 & 281 & 33.9 & 0.99 \\
\hline \multicolumn{5}{|l|}{ Body condition score } \\
\hline Average & 3.08 & 3.08 & 0.027 & 0.81 \\
\hline Change (U/30 d) & 0.03 & 0.03 & 0.018 & 0.94 \\
\hline \multicolumn{5}{|l|}{ Body locomotion score } \\
\hline Average & 1.43 & 1.49 & 0.047 & 0.16 \\
\hline Change (units/30 d) & -0.02 & 0.13 & 0.044 & 0.01 \\
\hline
\end{tabular}

a $n=247$; average days in milk at start of study $=218.5 \mathrm{~d}$.

Milk yield $(\mathrm{P}<0.05)$, milk fat yield $(\mathrm{P}<0.01)$, milk protein yield $(\mathrm{P}<0.01)$ and milk energy output $(\mathrm{P}<0.01)$ were higher for $\mathrm{B}$ vitamin blend cows. Milk protein proportion increased $(\mathrm{P}<0.01)$ with $\mathrm{B}$ vitamin blend feeding, whereas milk fat proportion was unaffected. Somatic cell count $(\mathrm{SCC})$ was lower $(\mathrm{P}<0.02)$ in cows fed $\mathrm{B}$ vitamins. Changes in BCS and BLS were both higher $(\mathrm{P}<0.01)$ with $\mathrm{B}$ vitamin feeding (Table 6$)$.

\section{Discussion}

It is not common to complete animal experiments in which more than one nutrient is added simultaneously as this makes it impossible to attribute the results to any one of those nutrients. However in the case of B vitamin metabolism, it is possible that the response of any B vitamin may depend on the availability of others, suggesting that the cumulative response of a group of B vitamins, particularly in protein metabolism, may be less than the impact of the group. However this design eliminates the possibility of determining if less than the group of added nutrients (in this case B vitamins) could have been solely responsible for the benefit.

The TMR ingredient composition for both experiments was typical of central California dairy rations, including ingredients such as corn and alfalfa silages, flaked corn grain and whole cottonseed. Each of the TMR generally exceeded nutrient requirements, as suggested by NRC (2001), for dairy cows in these productivity ranges. In addition, and in both experiments, there were no differences in the chemical composition between the TMR fed to control versus B vitamin blend cows, with the only difference between the TMR 
Table 6

Impact of feeding B vitamins on DM intake and production of $\operatorname{cows}^{\mathrm{a}}$ in Experiment 2

\begin{tabular}{|c|c|c|c|c|}
\hline & Control & $\mathrm{B}$ vitamin blend & S.E.M. & $\mathrm{P}$ \\
\hline DM intake $(\mathrm{kg} / \mathrm{d})$ & 23.0 & 22.3 & 0.38 & 0.44 \\
\hline \multicolumn{5}{|l|}{ Yield } \\
\hline Milk (kg/d) & 39.60 & 40.46 & 0.405 & 0.02 \\
\hline Fat $(\mathrm{kg} / \mathrm{d})$ & 1.40 & 1.47 & 0.017 & $<0.01$ \\
\hline True protein (kg/d) & 1.10 & 1.16 & 0.011 & $<0.01$ \\
\hline Energy (MJ/d) & 113.2 & 117.8 & 1.16 & $<0.01$ \\
\hline \multicolumn{5}{|l|}{ Milk components } \\
\hline Fat $(\mathrm{g} / \mathrm{kg})$ & 35.8 & 36.3 & 0.29 & 0.16 \\
\hline True protein $(\mathrm{g} / \mathrm{kg})$ & 28.0 & 28.7 & 0.12 & $<0.01$ \\
\hline Energy (MJ/kg) & 2.88 & 2.91 & 0.012 & 0.02 \\
\hline SCC ('000) & 611 & 349 & 81.5 & 0.02 \\
\hline \multicolumn{5}{|l|}{ Body condition score } \\
\hline Average & 2.93 & 2.96 & 0.016 & 0.08 \\
\hline Change (U/30 d) & 0.04 & 0.13 & 0.012 & $<0.01$ \\
\hline \multicolumn{5}{|l|}{ Body locomotion score } \\
\hline Average & 1.31 & 1.37 & 0.040 & 0.07 \\
\hline Change (U/30 d) & 0.00 & 0.12 & 0.031 & $<0.01$ \\
\hline
\end{tabular}

${ }^{\text {a }} n=247$; average days in milk at of study $=92.8 \mathrm{~d}$.

fed to the control and B vitamin blend groups being the B vitamin blend added to that diet.

\subsection{Impact of B-vitamins on productivity}

Feeding B vitamins had a positive impact in milk protein yield in both experiments, although the extent of the positive impacts on milk and milk component output was much higher in Experiment 2. The main difference between the experiments was the days in milk of the cows at the start of the experiments (219 versus 93 in Experiments 1 and 2, respectively), since the chemical compositions of the TMR were similar. Although actual milk yield, and milk energy output, were similar between experiments, cows in Experiment 1 (mid lactation) had a relatively higher DM intake relative to milk production than did those in Experiment 2 (early lactation) and so presumably lower ruminal escape of B vitamins from both dietary and rumen microbial sources. This may suggest that cows in an earlier stage of lactation may be more responsive to B vitamin supplementation due to decreased DM intake relative to milk production.

While experiments of the type used here are not generally designed to elucidate mechanisms of response, it is clear that the general increase in lactational performance in the absence of a change in DM intake, was probably due to increases in metabolic efficiencies in energy and protein metabolism, particularly in the early lactation cows, rather than due to increased DM intake. This is consistent with B vitamin supplementation research in non ruminant species that suggests improvements in growth are associated with improved feed efficiency rather than increased DM intake (Stahly et al., 2007). Our results could be inter- 
preted to suggest that the mechanism of action of supplemental B vitamins is to facilitate increased efficiency of metabolic function, rather than higher metabolic function per se, which would likely be accompanied by increased DM intake.

The main purpose of supplementing dairy cows with ruminally protected B vitamins in our study was to increase production of milk and milk components, in particular milk protein due the integral roles of $\mathrm{B}$ vitamins in milk protein synthesis. However, as there is little information about $\mathrm{B}$ vitamin requirements, dietary supplies, ruminal synthesis and duodenal flows of B vitamins in ruminants, it was difficult to formulate a B vitamin blend containing those that might have been limiting milk production, as well as decide on the appropriate level of each B vitamin. Thus the blend used in the present study was formulated based on the rationale outlined in Section 1, and it is possible that a blend with a different $B$ vitamin composition, or fed at different levels or to cows fed different diets, may have elicited a different response. Future research in this area should focus on dietary factors that modify ruminal synthesis and escape of B vitamins, as well as animal requirements for B vitamins at different stages of lactation, and effects of B vitamin supply on metabolic efficiency of dairy cows.

\subsection{Impact of $B$-vitamins on locomotion}

Lameness is a multi-factorial disorder that contributes to poor health, welfare and productivity in dairy cows throughout the world. Biotin has long been known to affect health and integrity of skin, hair, hooves in swine and horses, and footpads in poultry. Recently, several studies with dairy cattle have reported benefits, such as reduced somatic cell count and improvement of hoof health in cows fed $20 \mathrm{mg} / \mathrm{d}$ of supplemental biotin (Fitzgerald et al., 2000; Zimmerly and Weiss, 2001; Majee et al., 2003; Bergsten et al., 2003). In contrast to these findings with ruminally unprotected biotin alone, BLS increased in cows fed the B-vitamins in both experiments. Although hoof health was not the main purpose of this study, and no measures of it were made, it was expected that cows fed the B-vitamins might have had a decreased BLS based upon the prior research with biotin. A possible reason for this is that the hoof horn needs time to renew before effects of biotin, and potentially other B vitamins, on hoof health are expressed. For example, Fitzgerald et al. (2000) evaluated impacts of long term supplementation with biotin on prevention of lameness in dairy cows and reported a response to biotin supplementation, but only after 4 months of biotin feeding. Nonetheless, it is not known why cows fed the B vitamins responded with an increased BLS, and more research seems suggested in this area.

\section{Conclusions}

Supplying cows with a ruminally protected B vitamin blend containing biotin, folic acid, pantothenic acid and pyridoxine, increased milk and milk component yields, especially milk protein yield, to different extents in two lactation studies.

Differences in the extent of the positive responses in milk, milk fat and milk energy output between experiments perhaps suggests that they may depend on stage of lactation, with the possibility that early lactation cows, with lower ratios of DM intake to milk yield, 
may be more responsive than mid lactation cows with higher ratios of DM intake to milk yield. Results can be interpreted to suggest that the mechanism leading to the positive overall production response with B vitamin supplementation was due to improvements in metabolic efficiency of intermediary metabolism, rather than increased metabolic activity perse.

Because ruminal B vitamin synthesis, duodenal flow and animal requirements are poorly defined, a blend with a different B vitamin composition, or fed in different circumstances, could elicit a different response. More research is needed to support our results, and to determine the mode of action of supplemental B vitamins in dairy cows.

\section{Acknowledgements}

Appreciation is extended to the two farm crews for always being helpful and supportive throughout the experimental period, to Dr. Edward DePeters for the fat assays, to Ronaldo Cerri for support as a body scorer, and to the DHIA staff for providing milk sample assays.

\section{References}

Agrawala, L.P., Huffman, C.F., Luecke, R.W., Duncan, C.W., 1953. A quantitative study of rumen synthesis in the bovine on natural and purified rations. 3. Riboflavin, pantothenic acid and niacin. J. Nutr. 49, 631.

AOAC, 1997a. Fiber (Acid Detergent) and Lignin in Animal Feed. (Method 973.18). Official Methods of Analysis, 16th ed. AOAC International, Arlington, VA, USA.

AOAC, 1997b. Protein (Crude) in Animal Feed. (Method 990.03). Combustion Method, 16th ed. AOAC International, Arlington, VA, USA.

AOAC, 2000. Official Methods of Analysis of AOAC International (2000), 17th ed. AOAC International, Arlington, VA, USA.

Bergsten, C., Greenough, P.R., Gay, J.M., Seymour, W.M., Gay, C.C., 2003. Effects of biotin supplementation on performance and claw lesions on a commercial dairy farm. J. Dairy Sci. 86, 3953-3962.

Edmonson, A.J., Lean, I.J., Weaver, L.D., Farver, T., Webster, G., 1989. A body condition scoring chart for Holstein dairy cows. J. Dairy Sci. 72, 68-78.

Fitzgerald, T., Norton, B.W., Elliot, R., Podlich, H., Svendsen, O.L., 2000. Influence of long-term supplementation with biotin on the prevention of lameness in pasture fed dairy cows. J. Dairy Sci. 83, 338-344.

Frigg, M., Straub, O.C., Hartmann, D., 1993. The bioavailability of supplemental biotin in cattle. Int. J. Vitam. Nutr. Res. 63, 122-128.

Girard, C.L., Matte, J.J., Tremblay, G.F., 1995. Gestation and lactation in dairy cows: a role for folic acid? J. Dairy Sci. 78, 404-411.

Girard, C.L., Matte, J.J., 1998. Dietary supplements of folic acid during lactation: Effects on the performance of dairy cows. J. Dairy Sci. 81, 1412-1419.

Girard, C.L., Matte, J.J., 2005. Effects of intramuscular injections of vitamin B12 on lactation performance of dairy cows fed dietary supplements of folic acid and rumen-protected methionine. J. Dairy Sci. 88, 671676.

Johansen, H.N., Glitso, V., Knudsen, K.E.B., 1996. Influence of extraction solvent and temperature on the quantitative determination of oligosaccharides from plant materials by high-performance liquid chromatography. J. Agric. Food Chem. 44, 1470-1474.

Johnson, C.M., Ulrich, A., 1959. Analytical methods for use in plant analysis. Bulletin 766. University of California Agricultural Experiment Station, Berkeley, CA, USA, pp. 26-78.

Lardinois, C.C., Mills, R.C., Elveiijem, C.A., Hart, E.B., 1944. Rumen biosynthesis of vitamin B complex as influenced by ration composition. J. Dairy Sci. 27, 579-588. 
Majee, D.N., Schwab, E.C., Bertics, S.J., Seymour, W.M., Shaver, R.D., 2003. Lactation performance by dairy cows fed supplemental biotin and a B-vitamin blend. J. Dairy Sci. 86, 2106-2112.

McElroy, L.W., Goss, H., 1940a. A quantitative study of vitamins in the rumen contents of sheep and cows fed vitamin low diets. I. Riboflavin and Vitamin K. J. Nutr. 20, 527-540.

McElroy, L.W., Goss, H., 1940b. A quantitative study of vitamins in the rumen contents of sheep and cows fed vitamin low diets. II. Vitamin B6. J. Nutr. 20, 541-556.

Meyer, G.A., Keliher, P.N., 1992. An overview of analysis by inductively coupled plasma-atomic emission spectrometry. In: Montaser, A., Golightly, D.W. (Eds.), Inductively Coupled Plasmas in Analytical Atomic Spectrometry. VCH Publishers Inc, New York, NY, USA, pp. 473-505.

NRC, 2001. Nutrient Requirements of Dairy Cattle. National Academy of Sciences, Washington, DC, USA.

Reuter, D.J., Robinson, J.B., Peverill, K.I., Price, G.H., 1986. Guidelines for collecting, handling and analyzing plant materials. In: Reuter, D.J., Robinson, J.B. (Eds.), Plant Analysis an Interpretation Manual. Inkata Press, Melbourne, Australia, pp. 20-35.

Sah, R.N., Miller, R.O., 1992. Spontaneous reaction for acid dissolution of biological tissues in closed vessels. Anal. Chem. 64, 230-233.

Santschi, D.E., Berthiaume, R., Matte, J.J., Mustafa, A.F., Girard, C.L., 2005. Fate of supplemental B-Vitamins in the gastrointestinal tract of dairy cows. J. Dairy Sci. 88, 2043-2054.

SAS User's Guide: Statistics, Version 7 ed. SAS Inst., Inc. Cary, NC, USA, 1998.

Schwab, E.C., Schwab, C.G., Shaver, R.D., Girard, C.L., Putnam, D.E., Whitehouse, N.L., 2006. Dietary forage and nonfiber carbohydrate contents influence B-vitamin Intake, duodenal flow, and apparent ruminal synthesis in lactating dairy cows. J. Dairy Sci. 89, 174-187.

Seymour, W.M., 2000. Biotin, hoof health and milk production in dairy cows. In: 12th Annual Florida Ruminant Nutrition Symposium, FL, USA, pp. 70-78.

Shaver, R.D., Bal, M.A., 2000. Effect of dietary thiamin supplementation on milk production by dairy cows. J. Dairy Sci. 83, 2335-2340.

Smith, D., 1969. Removing and Analyzing Total Nonstructural Carbohydrates from Plant Tissue. Wisconsin Agric. Exp. Sta. Res. Report 41, Madison, WI, USA.

Sprecher, D.J., Hostetler, D.E., Kaneene, J.B., 1997. A lameness scoring system that uses posture and gait to predict dairy cattle reproductive performance. Theriogenology 47, 1179-1187.

Stahly, T.S., Williams, N.H., Lutz, T.R., Ewan, R.C., Swenson, S.G., 2007. Dietary B vitamin needs of strains of pigs with high and moderate lean growth. J. Anim. Sci. 85, 188-195.

Tracy, M.L., Moeller, G., 1990. Continuous flow vapor generation for inductively coupled argon plasma spectrometric analysis. Part 1: Selenium. J. Assoc. Off. Anal. Chem. 73, 404-410.

Tyrrell, H.F., Reid, J.T., 1965. Prediction of the energy value of cow's milk. J. Dairy Sci. 48, 1215-1223.

Van Soest, P.J., Robertson, J.B., Lewis, B.A., 1991. Methods for dietary fiber, neutral detergent fiber and non-starch polysaccharides in relation to animal nutrition. J. Dairy Sci. 74, 3583-3597.

Welch, J.G., 1990. Inert plastics as indicators of physiological processes in the gastrointestinal tract of ruminants. J. Anim. Sci. 68, 2930-2935.

Zimmerly, C.A., Weiss, W.P., 2001. Effects of supplemental biotin on performance of Holstein cows during early lactation. J. Dairy Sci. 84, 498-506.

Zinn, R.A., Owens, F.N., Stuart, R.L., Dunbar, J.R., Norman, B.B., 1987. B-vitamin supplementation of diets for feedlot calves. J. Anim. Sci. 65, 267-277. 